\title{
Reappraising Zhang Zhidong: Forgotten Continuities During China's Self-Strengthening, 1884-1901
}

\author{
Adam Chang \\ Captain, United States Army \\ Adam.Chang@usma.edu
}

\begin{abstract}
The recent historiography of China's late nineteenth-century Self-Strengthening movement emphasizes the successes in Chinese state building. My research expands upon this trend through the perspective of the prominent governor-general Zhang Zhidong 張之洞 (1837-1909) and his military reforms. From 1884 to 1901, Zhang consistently pursued the creation of new military academies and western-style armies with the aim of providing an army capable of defending China. At the turn of the century, Zhang's military apparatus was arguably one of the best in China. However, his role as a military pioneer of this era was often obscured by the wider narratives of Chinese reforms or subsumed under the reforms of more notorious officials such as Li Hongzhang or Yuan Shikai. Ultimately, the study of Zhang Zhidong's reforms reveals an often-missed continuity in successful military reform starting in the 1880 s and contributes to the developing historical narratives of successful late Qing state building.
\end{abstract}

\section{Keywords}

Zhang Zhidong - Late-Qing - military reform - Self-Strengthening - military academy - New Armies

* I would like to thank the editor and anonymous reviewers for their guidance and insights. In addition, the views expressed in this article are those of the author and do not reflect the views of the Department of the Army, the Department of Defense, or the U.s. Government. 
After a series of exchanges with western militaries in the nineteenth century, China started upon the path of military reform in order to match or exceed western military capabilities. The process of state transformation known as the Self-Strengthening movement included the pursuit of new methods of industrial production, armament, and training in order to increase military efficacy. Chinese officials such as Zeng Guofan, Li Hongzhang, and Zhang Zhidong led these efforts to expand the military capabilities of their state. As the Qing military reforms were predominantly provincial-level projects, studies of the key provincial figures may provide the fullest exploration of these developments. Furthermore, the central government's unwillingness to direct military reforms until after the Boxer Rebellion left military development in the hands of provincial officials. ${ }^{1}$ Even when the Qing court finally took up the task of transforming the entire Chinese military, they looked to the advancements men such as Zhang Zhidong had made during the last half of the nineteenth century. Thus, it may be possible to learn more about the military reforms by studying a Chinese official like Zhang rather than simply focusing on the central government. Zhang Zhidong saw the state of nineteenth-century military affairs and grasped the need for change. Zhang's career took him through three separate governor-generalships from 1884 to 1907-Liangguang, Huguang, Liangjiang, then back to Huguang - with military projects pursued in each. Through his peripatetic career and its multitude of new military institutions, the continuities and changes of late Qing military reforms can be more easily discerned.

The early historical narratives of the Self-Strengthening movement started as stories of failure. Historians initially ascribed this failure to the cultural obstructionism of entrenched Chinese tradition. For example, John K. Fairbank argued the "movement of westernization was obstructed at every turn by the ignorance and prejudice of the Confucian literati." Fairbank also dismissed Zhang Zhidong's famous ti-yong 體用 (lit. "structure-use") thesis of “Chinese learning as the fundamental structure, western learning for practical use" as "misleading" in its promotion of the "fallacy of halfway westernization." This emphasis on Confucian conservatism also applied to the historiography

1 In this study, governors-general such as Zhang Zhidong will be referred to as "governor" unless it is important to differentiate the relative ranks of two officials or jurisdictions. An outline of the Qing government structure can be found in Guy 2010, 56-59. Another useful work outlining the Chinese government structure is Morse 1967, 35-61.

2 Fairbank 1992, 217. The ti-yong thesis is short for “zhongxue wei ti, xixue wei yong” 中學為體, 西學為用, and translates to "Chinese learning as the fundamental structure, western learning for practical use." 
of military reforms. In many early historical accounts, the military reforms of the Self-Strengthening movement were perceived as failures, with the Chinese losses in the Sino-Japanese War in 1895 and the Boxer Rebellion in 1900 serving as the self-evident proofs. ${ }^{3}$ One of the few works before the late 199os that depicted limited successes in the Chinese military reforms was Ralph Powell's seminal The Rise of Chinese Military Power, which detailed many successful aspects of Zhang Zhidong's military reforms. ${ }^{4}$ Yet within this wider analysis, the specific nature of Zhang's programs tended to be lost in the larger narrative of late Qing military developments.

After the early 1990s, historical narratives of the Self-Strengthening movement began to identify different strands of successful late Qing state building. William T. Rowe's survey of the late Qing observed that more recently historians have focused upon successes in areas such as shipbuilding, commerce, and manufacturing. ${ }^{5}$ Although these successful efforts at reform did not prevent the Qing collapse, recent historians have argued that the reforms did allow China to maintain "strategic capabilities beyond the minimal threshold to retain its independence." ${ }^{6}$ While Ralph Powell's earlier assessments cast doubt on the failure of Self-Strengthening, the recent historiography has progressed to include positive effects of late Qing state building. This historiographical development also included a renewed focus on late Qing military reforms. For instance, Allen Fung's 1996 analysis of the military operations in the SinoJapanese War showed the land campaigns were more closely matched than commonly presented. ${ }^{7}$ Similarly, Edward McCord argued that Zhang Zhidong's pioneering use of western military organization in 1895 at Nanjing was one of the key factors in late Qing state building that would influence the development of the following warlord period. ${ }^{8}$ The latest reevaluations of Zhang Zhidong's military reforms thus support the recent historiographical narratives

3 For instance, Cyrus Peake's account of Chinese education argued that meaningful educational reform, including military education, did not take place until after 1900. See Peake 1970, 24-25. Similarly, Knight Biggerstaff argued that military conservatism led to Qing failure in the Sino-Japanese War. See Biggerstaff 1961, 85-86. See also Ayers 1971.

4 Ralph Powell's work emphasizes the role of Zhang Zhidong's reforms in Liangjiang as the first instance of true organizational and institutional change over Zhang's earlier reforms in Liangguang and later reforms in Huguang. See Powell 1955, 61-62, 69-70. Chinese authors such as Zhang Yiwen have also attributed a similar primacy to Zhang Zhidong's Nanjing reforms. See Zhang 2009, 370.

5 Rowe 2009, 218-19.

6 Halsey 2015, 147-50.

7 Fung 1996, 1029.

8 McCord 1993, 33 . 
of successful late Qing state building. Yet as was the case in previous works, the continuities and changes represented by the governor's reforms have tended to be lost in the larger narrative.

Li Xizhu's Zhang Zhidong yu xinzheng yanjiu (A Study of Zhang Zhidong and the Late Qing New Policies) focused exclusively on Zhang's career and thus identified more distinct continuities between his military reforms in different jurisdictions. Contrasting with many English-language studies of the period, Li's work studied Zhang's reforms specifically while connecting his policies from the governorship of Liangjiang to that of Huguang. ${ }^{9}$ However, while Li identified the continuities between the Liangjiang era and the impact of Zhang's later reforms in Huguang, he nonetheless dismissed the governor's early reforms in Liangguang because Zhang "did not have awareness of the Chinese-foreign military affairs gap."10 Furthermore, even in his assessment of Zhang's governorship of Huguang, Li quickly moved past the preceding Hubei Protection Army and the Hubei Military Academy to the Hubei Regular Army and three-tiered academy system as the culmination in 1902-3. ${ }^{11}$ In doing so, Li missed a key difference between two phases of the Huguang reforms. The post-Boxer Rebellion reforms represented Zhang Zhidong's compliance with centrally mandated programs more than his own ideas. In contrast, the earlier 1896-1901 reforms in Huguang were pursued solely on Zhang's own initiative. Simply put, by not distinguishing between the Qing-mandated reforms and Zhang's initiatives, Li made Zhang's own reform efforts appear less consistent and continuous with his earlier programs. Thus, while Li Xizhu's work was highly successful in showing certain continuities of Zhang's career, it also left space for different interpretations.

While historians in both China and the West have recognized Zhang's importance, his military reforms themselves have not yet fully entered the narrative. China's modern military development is a story of both change and continuity, but the latter aspect has not been fully integrated into the developing historiography. A focused examination of Zhang Zhidong's military reforms may bring to light some forgotten continuities. Informed by the observation of organizational changes after the Sino-Japanese War, historians have tended to see this conflict as a turning point or new departure in China's military reform process.

Li argues that Zhang Zhidong is the founding father of modern Chinese military institutions, and further asserts the importance of Zhang Zhidong's roles in the Huguang era after 1895 as equally if not more important than his work in Liangjiang. See Li 2009, 24751,254 .

$10 \quad$ Li 2009, 217-18.

$11 \quad$ Li 2009, 247-51. 
Yet Zhang Zhidong's unique governorship career starting in Liangguang challenges this historical placement of key reforms in China's military forces. This alone justifies a new look at Zhang's military reforms spanning from the early 188 os through the early 1900 .

Zhang Zhidong's career offers a unique perspective that reinforces the recent historiographical developments. I argue that while Zhang was culturally conservative, he nonetheless pioneered radical progress in China's military organizations and institutions by adapting traditional Chinese culture to contribute to the successful state building of the late Qing. Furthermore, these institutional military reforms started earlier than commonly presented. Throughout his career, Zhang continuously increased his military knowledge and reform experience, often through trial and error. The lessons he learned from undertaking reform, combined with the specificities of his various jurisdictions, often appeared as discontinuities. These apparent discontinuities in Zhang's reforms led to inaccurate assessments of the extent of his programs as well as his intent in establishing them. In fact, Zhang Zhidong's peripatetic governor-generalships from 1884 to 1901 maintained consistent principles embodied by the institutional organization of his western-style armies and military academies. These military organizations represented a crucial transitional form between the older Self-Strengthening armies of Zeng Guofan and the post-Boxer Rebellion centralized militaries. Yet the Eurocentric western observers of the time often missed the fact that Zhang promoted classical Chinese education within western military institutions, resulting in a historiographical distortion of Self-Strengthening military reform.

\section{Liangguang, Early Huguang, and the Foundations of Reform}

Zhang Zhidong's career as a Qing official started upon his attainment of the metropolitan jinshi degree in 1863. After he passed the national-level examinations, the Qing court assigned Zhang to various educational positions until his first provincial assignment, in which he started a career-long propensity toward promotion of education. He served in these educational posts until he was transferred in 1882 to serve as the governor of Shanxi province. During his time as the Shanxi governor, Zhang memorialized the throne about the Sino-French clashes in Annam, resulting in his promotion to the governorgeneralship of the Liangguang region (which encompassed the provinces of Guangdong and Guangxi). ${ }^{12}$ The Liangguang tenure would be the foundation 
for Zhang's military reform efforts throughout his extensive official career. There, Zhang established a military academy embodying the ti-yong dichotomy for which he would become famous. He studied and documented western military capabilities, developed western-style armies, and initiated lasting relationships with German officers. It was also in the Liangguang governorship that Zhang developed the framework for spreading military reforms throughout the army. In other words, the Liangguang tenure was the time in which the newly promoted Governor Zhang developed the comprehensive reform program, centered upon the western-style army and military academy, that he would pursue for the rest of his career. It was also in these early relationships with the west that Zhang began to understand the need for military reforms to maintain not only Chinese state authority over foreign advisors but also Confucian ethical authority over the new Chinese military formations. Even as the environment changed in Zhang's later jurisdictions, the systems established in Liangguang remained at the center of his military reform efforts for the next two decades.

\section{New Methods of Warfare: The Guangdong Victorious Army}

After the conclusion of the Sino-French War in June of 1885, Zhang Zhidong set about reforming the military forces of Liangguang. These early military reforms were the least documented of all of Zhang's governor-generalships. Zhang's own memorials directly pertaining to military reform consisted of one for the Guangdong Victorious Army (Guangsheng jun 廣勝軍) and another for the Guangdong Military Academy. The only other memorial relating to Zhang's military reform effort was his report on the recruitment of German officers to support his new institutions. Zhang Zhidong's first military reform memorial, to establish a western-style army in Guangdong, was submitted to the throne on July 7,1885 . Zhang provided details on creating the new army and his justification for why changes were needed. While historians have noted the existence of the new army, few have studied the governor's intentions on why and how to develop it. Ultimately, it was the lessons Zhang learned from the Sino-French War that prompted his reform efforts through the adoption of western techniques and stringent recruiting requirements. In the reform process, Zhang used German instructors to drill his new army and disseminated the new training through a small nucleus of trained troops. This was Zhang's first foray into the western-style military, a force he named the Guangdong Victorious Army.

Zhang Zhidong studiously observed the events of the Sino-French War in order to apply their lessons to his reforms. He identified several crucial advantages of the western military over the Chinese: artillery and machine gun support to provide concentrated firepower, engineers to provide combat mobility, 
and the hardiness of individual soldiers who were able to fight with heavy combat loads. ${ }^{13}$ In other words, one of the prime areas of reform Zhang identified was improving the Chinese army's ability to maneuver and concentrate combat power like the western forces he observed. Furthermore, the technical advantages of artillery and machine-gun fire would allow for concentration of combat power even without numerical superiority in troops. More importantly, Zhang did not underestimate the difficulty of this task. He stated that to achieve "accurate artillery, rifle marksmanship, fortifications, training is essential, [and] that these military techniques can only be trained in peacetime."14 The governor recognized that modern soldiering could not be learned quickly and the old Chinese methods of recruiting and training new soldiers in times of war were no longer effective. Zhang directly reflected upon this point by invoking the Huai Army as an example of a force armed with western weaponry but not trained effectively on the use of their armaments. ${ }^{15}$ In establishing his own Guangdong Victorious Army, Zhang both armed and trained troops to form the standing peacetime army required to cultivate military competence.

For his new Guangdong Victorious Army, Zhang started reforms with a single battalion as the core and quickly established strict recruitment standards for the soldiers. Inspired by the observed hardiness of western soldiers during the war, Zhang similarly required his new soldiers to be those that were "strong and fit, who can accept the constraints of heavy work and hardship."16 Aside from physical standards, Zhang's recruitment of forces included a new characteristic that carried throughout his later reforms, widespread recruitment. Men of all social statuses and from any province could apply to join the Guangdong Victorious Army. ${ }^{17}$ In casting a wide net of recruitment, the governor was effectively gathering the most fit and talented across as large an area as possible. His stringent recruiting criteria combined with a multi-provincial recruitment attempted to rectify the problems of poor human material in the Chinese military.

To train his army, Zhang hired German officers through the Chinese minister to Germany, He Xianchi. The German ministry approved his request, and by October of 1884 all three German officers had arrived and started training the

13 Zhang Zhidong, "Jiaolian Guang Shengjun zhuan xi yan zhan pian" [Educating the Guangdong Victorious Army in western warfare], ZZDQJ, I, 313.

14 Zhang, "Jiaolian Guang Shengjun ...," ZZDQJ, I, 313.

15 Zhang, "Jiaolian Guang Shengjun ...," ZZDQJ, I, 313.

16 Zhang, "Jiaolian Guang Shengjun ...," ZZDQJ, I, 313.

17 Zhang, "Jiaolian Guang Shengjun ...," ZZDQJ, I, 313-14. 
army. ${ }^{18}$ The German officers instructed the Guangdong Victorious Army according to western methods but under Zhang's guidance. To address the weaknesses he had identified earlier-limited combat mobility and the inability to concentrate firepower - the governor tasked the Germans to train "artillery accuracy, marksmanship, dispersed squad movements, night warfare, rapid movement, crossing moats and mountain warfare."19 Zhang also proposed a role for the Germans in time of war. He received approval to give the German officers Chinese military rank and assumed these officers would command Chinese soldiers until Chinese officers were trained. ${ }^{20}$ While this situation never materialized, Zhang's openness to German command foreshadowed his later Nanjing reforms.

In Guangdong, Zhang also established his method of using the newly trained troops as the nucleus to create new western-armed and trained battalions. ${ }^{21}$ This method had both negative and positive implications when compared to a more widespread training program. While his method was likely to be both slower and risk miscommunication as the training was passed from unit to unit, it would also require fewer foreign instructors and hence reduce expenses. The costs of foreign officers were not insignificant as Zhang's contract required him to pay each of them 3,6oo taels a year while providing room and board. ${ }^{22}$ Comparatively, the senior ranking Chinese officer in Zhang's later Nanjing Self-Strengthening Army was paid 600 taels a year, while a Chinese soldier received about 60 taels a year. ${ }^{23}$ A German instructor's salary was at least sixty-fold that of the Chinese soldier and six times that of the most senior Chinese officer. This figure is even more telling when one recognizes the fact that Zhang's army was significantly better paid than traditional Chinese soldiers. Even though the financial cost was high, Zhang's use of small-nucleusbased training was able to mitigate the burden.

While short-term cost reduction was achieved in this way, the more effective long-term solution involved training competent Chinese military officers able to lead their own soldiers. This fact was not lost on Zhang Zhidong, as the

18 Zhang Zhidong, "Gumu De bian pian" [Recruiting German officers], ZZDQJ, I, 315.

19 Zhang, "Jiaolian Guang Shengjun ...," ZZDQJ, I, 313.

20 Zhang, "Gumu De bian pian," ZZDQJ, I, 315.

21 Zhang, "Gumu De bian pian," ZZDQJ, I, 314.

22 Zhang, "Gumu De bian pian," ZZDQJ, I, 314.

23 Zhang 2009, 374. While salaries of Zhang's Chinese soldiers were high, they remained lower than the traditional Qing officers' salaries. Under Qing pay scales, the lowest ranking military officer earned 125.9 taels a year in both salary and allowances. See Chang $1962,13-15$. 
second part of his military reforms in every jurisdiction focused on the education of officers. In training officers who understood western warfare's technology, requirements, and training, Zhang could not only save on long-term costs but also ensure his newly trained armies had effective combat leadership. The root of officer training was the military academy.

\section{Integrating East and West: The Guangdong Military Academy}

Zhang Zhidong founded the Guangdong Military Academy in 1887. As a promoter of broad education throughout his career, Governor Zhang sought to ensure the continuation of classical Chinese education for his cadets by integrating it with the new western military education. The military education at the Guangdong Military Academy outpaced that in the Guangdong Victorious Army as officers were not only trained in western warfare, but also organized institutionally along western lines. Furthermore, Zhang's focus on traditional educational endeavors combined with the new military education served as an early application of his ti-yong formula. This early, practical form of Zhang's "Chinese learning as the foundation and western learning for practical use" would continue to inform the curriculum and admissions requirements of his military academies in his later jurisdictions.

In addition to the stringent physical hardship requirements, Zhang Zhidong's admissions criteria to the Guangdong Military Academy also sought applicants with baseline western knowledge and Chinese literary education. Specifically, Zhang recruited from various institutions including western schools in Guangdong, as well as drawing from a pool of the "literary men" and army officers who had already obtained degrees. The governor further detailed the reasons for the broad admissions criteria in finding "those having mastered some Western language and mathematics ... experienced soldiers' hardships ... and have studied [Chinese literature] and are capable of writing essays." ${ }^{24}$ The governor's admissions requirements blended Confucian classical education with the hardship of western military training and basic western elementary education. While these students would come from different backgrounds, their shared experience and education at the Guangdong Military Academy was intended to unite those with diverse experiences into a new western-style officer corps. Of particular note was Zhang's guidance that cadets from Chinese literary and army backgrounds were to be given more than half of the slots in his

\footnotetext{
24 Zhang Zhidong, "Chuangban shui lu si xuetang zhe" [Establishing the Naval and Military Academy], ZZDQJ, I, 575 .
} 
new institution. His insistence on using those with traditional Chinese backgrounds in his schools would continue throughout his later academies.

Zhang Zhidong's Guangdong Military Academy also reveals that western institutional changes to military organizations started earlier than historians have presumed. Bringing the military academy in line with western models, Zhang's Guangdong Military Academy tasked foreign officers to teach German, but more importantly divided the school in accordance with western organizational precedents. At this newly created military academy, Zhang followed western models by "organization into three branches of cavalry, artillery, and infantry."25 While historians using similar evidence from Zhang's memorials have pointed to his later Self-Strengthening Army as the first organized under western models, they missed the fact that the same western military organization occurred in the Guangdong Military Academy. ${ }^{26}$ This fact shifts the timeline of our historical understanding of when Chinese officials began truly undertaking institutional military reform. Zhang Zhidong's Guangdong Military Academy shows that at least some officials began to adopt truly western military organization as early as the 188 os, instead of after the SinoJapanese War.

Yet Zhang's academy did not simply abandon Chinese education for a western model, but instead forged a further synthesis of western and Chinese thought in his curriculum. Thus, in addition to organizing and training future officers in the three basic European combat arms, Zhang required the cadets to maintain their Chinese literary education. For Zhang, western military education without Chinese foundation was not enough. Again, in promoting a broad education for his officers, the governor established Chinese classical education on top of the western curriculum. "Early every morning, the students shall all review the Four Books and Five Classics for about an hour," and on Sundays they will "review the classics and histories and write discourses and essays [on]

25 As Zhang stated in his memorial "feng ma bu, qiangpao, yinzao sanxiang." Zhang, “Chuangban shui lu si xuetang zhe," ZZDQJ, I, 575 .

26 Evidence of historical evaluations of the novel western models starting in Zhang's SelfStrengthening Army can be seen in many historical assessments. Even relatively recent historians such as Edward McCord have argued Zhang's first real organizational improvement was "as governor-general at Nanjing in 1895 he had pioneered the introduction of Western military organization with the establishment of the Self-Strengthening Army." See McCord 1993, 33. Ralph Powell also gave a similar but more detailed assessment in stating that Zhang's Self-Strengthening Army was one of the first in China to be organized along western lines in that it "comprised the three basic arms, independently organized." See Powell 1955, 61-62. For other similar historical assessments see: Li 2009, 219; Wang 1995, 69; Zhang 2009, 373. 
literature, history, and military science of China.... so they may not lose their fundamental knowledge." ${ }^{27}$ The inclusion of classical Chinese literary education clearly showed Zhang's emphasis on traditional academics while reorganizing officer education along western institutional lines. Zhang's policies on the imperial examinations were just as telling of his beliefs. The only other Chinese military academy at the time, the Tianjin Military Academy, forbade participation in the imperial examinations. ${ }^{28}$ In contrast, Zhang Zhidong's Guangdong Military Academy specifically authorized the cadets to take the examinations. Zhang's memorial stated that "students who during their terms of study wish to participate in the civil and military competitive examinations shall be accorded the privilege."29 By allowing his cadets to take the civil and military examinations, Zhang reinforced the importance of the Confucian education. The dichotomy of Western military education during the day combined with pre-class and Sunday study of the Chinese classics exemplified Zhang's ti-yong methodology. In the larger context of Confucian ideology and the state, Zhang argued against the prevalent notion among traditionally educated Chinese elites that one had to be either classical or modern by showing them that their sons could serve in a military academy that was both Confucian and modern.

Zhang Zhidong's Guangdong Military Academy represented the principles of military reform he espoused. In recruiting, he selected cadets who were capable of enduring the hardship of western drill and learning the basics of a western language, while remaining firmly rooted in Confucian values. While he was unable to find men meeting all these criteria, the governor did enroll cadets who met one or another of them and hoped to unite their respective contributions. Zhang further blended traditional Chinese education and western military education through his established curriculum. The Guangdong Military Academy organized the cadets into western tables of organization and taught western military studies, while also studying Chinese literary and military classics. In establishing the first of his schools, Zhang set for himself the principles of admissions and curriculum he would repeat throughout his career.

\section{Liangguang Assessment}

During Zhang Zhidong's career as a governor-general, the progress he made in Guangdong was the least recorded-only documented in a small

\footnotetext{
27 Zhang, "Chuangban shui lu si xuetang zhe," zZDQJ, I, 575.

28 "The New Military College at Tientsin," North China Herald, April 13, 1887, 417.

29 Zhang, “Chuangban shui lu si xuetang zhe," ZZDQJ, I, 575.
} 
paragraph from the Imperial Maritime Customs. There was little mention of any assessment of the military academy other than its existence and curriculum previously covered. ${ }^{30}$ This absence of material may have been due to the short year- and-a-half operation of the academy prior to Zhang's transfer to his next assignment. As William Ayers pointed out, the following governor-general of Liangguang dismantled Zhang's military reforms and institutions by $1892 .{ }^{31}$ However, even though the Liangguang military academy operated for only a short period, Zhang Zhidong not only gained valuable experience in creating western military institutions, but also later drew upon these early graduates for his future reform projects.

Even as early as his Liangguang tenure, Zhang Zhidong did not perceive his military reforms as westernization, but as learning from the foreigner's methods while distrusting the same foreigner's intentions. The governor's assessment of the Germans as the only trustworthy western nation, who "never used the [Sino-French] war as an excuse not to assist us," also revealed his distrust of the West as a whole. ${ }^{32}$ By showing the Germans as the most amicable and trustworthy, he implied that other westerners were not. Furthermore, even though he saw the Germans as the most honest of the westerners, Zhang nonetheless took measures to safeguard their loyalty and service to China. In his 1885 memorial to the throne, Zhang asked the emperor not only to assign the German officers Chinese rank but also to authorize Chinese military uniforms and tassels for them to wear. Zhang envisioned the Germans directly serving as Chinese officers if the need arose, and the emperor approved his request. ${ }^{33}$ By the time Zhang established his next western-style army, he had foregone the Chinese uniforms and rank for different methods of control.

The assessment of the Guangdong Victorious Army itself showed mixed results. While the improvement in training and foreign drill was noted, the "equipment and arming of the land forces are far from uniform."34 The problem of diverse weaponry could have created significant sustainment drawbacks resulting in the loss of operational and tactical capability. For example, if an infantry company carried three makes of rifles they also had to carry three types of ammunition. Diverse weaponry thus created supply challenges in requiring ammunition, weapons, and maintenance from multiple sources. More important were the tactical ramifications: if a third of a company ran out of

\footnotetext{
$30 \quad$ Imperial Maritime Customs, Decennial Reports 1882-1891, 576.

31 Ayers 1971, 113.

32 Zhang, "Gumu De bian pian," ZZDQJ, I, 314.

33 Zhang, "Gumu De bian pian," ZZDQJ, I, 314-15.

34 Imperial Maritime Customs, Decennial Reports 1882-1891, 576.
} 
ammunition, the unit could not cross-load supplies-effectively reducing its combat power without having suffered casualties.

Zhang did make some initial efforts to promote uniform armaments though his purchase request to the Krupp Company. ${ }^{35}$ But even with the additional equipment bought from Krupp, it appears the Guangdong Victorious Army was far from uniformly equipped. One contributing factor was Zhang's inability to produce his own armaments in Liangguang. It is no surprise that when the throne reassigned Zhang Zhidong to Huguang in 1889, one of his first acts was to build an arsenal in order to produce modern weapons in his own jurisdiction.

\section{Early Military Reforms of the Iron Works and Arsenal}

The Qing Court reassigned Zhang Zhidong to his new position as governor of Huguang (encompassing the provinces of Hubei and Hunan) in 1889 based on his recommendation to construct the Beijing-Hankou Railway. The conventional historical narrative of Zhang's first tenure in Huguang focuses upon his achievements in industry-specifically his creation of the Hanyang Iron and Steel Works. ${ }^{36}$ Historians' descriptions of Zhang's industrial and economic progress during this period came at the expense of exploring his military reforms. In fact, William Ayers attributed the perceived lull in Zhang's military reforms to "feelings of false security [created] by the relative quiet prevailing then in foreign relations." ${ }^{37}$ Although the relative peace likely had a role, the context of the governor's military reform experiences in Liangguang provides an alternative explanation. Zhang had been unable to equip his Guangdong Victorious Army uniformly using only purchases of western armaments. Furthermore, Zhang's primary purpose in Hubei- to establish the railwaywas first and foremost that of security. In Huguang, Zhang thus sought to improve conditions for later military reforms by first establishing the Hubei Arsenal in conjunction with the Iron Works supporting the railway. Both the rail and arms industries produced components essential to strengthening the military capabilities of the state-the transportation and sustainment of armies as well as the uniform and modern arming of troops.

Zhang's justifications for constructing railways reveal the national security mindset of the governor in his early Huguang years. In his 1889 Beijing-Hankou railway memorial, Zhang emphasized the criticality of the proposed railway in rapidly transferring troops between north and south China. The governor

\footnotetext{
35 Zhang, "Jiaolian Guang Shengjun ...," ZZDQJ, I, 314.

36 Hummel 1943, I, 29.

37 Ayers 1971, 113 .
} 
also argued that interior railways would not allow foreign invaders easy access, as they would not touch any ports of debarkation where foreign troops might land. ${ }^{38}$ Zhang Zhidong's argument for the Beijing-Hankou railway invoked a national context of development that contended with late Qing regionalism. Zhang wanted a railway that did not strengthen one province in lieu of another but improved China as a whole so that it could combat foreign incursions. With this justification in mind, Zhang's activity in Huguang no longer looks like a governor ignoring military matters during a time of peace in an effort to consolidate regional power. Instead, Zhang's actions were those of an official who understood and pursued the operational requirements of war on a national scale.

While the Hanyang Iron and Steel Works undoubtedly supported railway construction as its primary purpose, its ancillary functions were equally important. An often-ignored aspect of Zhang's industrial developments was the Hubei Arsenal section of the Iron Works. The Hankou customs commissioner in 1891, R.B. Moorhead, reported the arsenal would soon be able to produce a hundred artillery pieces, fifteen thousand rifles, and their associated ammunition "of the newest description" every year. ${ }^{39}$ Less than two years after being transferred to Huguang, Zhang had already established the manufacturing base needed to supply his new jurisdiction with modern armaments. Production figures in Moorhead's next report in 1901 showed the Hubei arsenal churning out about thirty Mauser rifles and five artillery pieces of modern make every day. ${ }^{40}$ Although a little short of Moorhead's initial estimates in 1891, the Hubei Arsenal still produced over ten thousand rifles a year. More importantly, these rifles were not only of modern make but also addressed the problems of armament uniformity Zhang had experienced in his Guangdong Victorious Army.

In his first six-year tenure as the governor of Huguang, Zhang Zhidong attempted to create an industrial and infrastructural base for the military. While the railway construction reform was eventually shelved until after the Sino-Japanese War due to budgetary issues, Zhang's intention to create rapid cross-provincial military transportation was nonetheless evident. In fact, the governor's infrastructural objective of connecting Hubei and Beijing showed he was thinking beyond the provincial or regional scale to provide security for the Qing empire as a whole. Yet transportation alone was not enough. From his experience in Liangguang, Zhang recognized the need for domestic armament manufacturing. During his first years as Huguang governor, he set the

38 Cameron 1938, 196.

39 Imperial Maritime Customs, Decennial Reports 1882-1891, 190.

40 Imperial Maritime Customs, Decennial Reports 1892-1901, 306. 
grounds for future reforms by constructing the Hubei Arsenal capable of supporting armies with modern western rifles and artillery pieces. Unfortunately, before Zhang could create any new armies or military academies the First Sino-Japanese War erupted in 1894. As a result of the hostilities, the Qing court shifted the Liangjiang governor north and transferred Zhang Zhidong to serve in his stead.

\section{Liangjiang's Financial Prosperity and Military Reforms}

By the spring of 1895, Japan's victory in the Sino-Japanese War became apparent. With the capture of Weihaiwei, the Japanese Army directly threatened Beijing and forced the Qing court to sue for peace or risk their regime. ${ }^{41}$ The renewed attention on military affairs due to the Sino-Japanese War, supported by the prosperous economic conditions of the Liangjiang area (encompassing the provinces of Anhui, Jiangsu, and Jiangxi), helped Zhang turn his ideas into action. During his sixteen-month tenure as governor of Liangjiang, he took action on all tenets of his military reform program. Zhang built a new western-style army commanded by German officers serving under the authority of a Chinese official. To lead the new army, Zhang again established a military academy to cultivate human talent that was not only competent in western warfare but also rooted in Chinese classical education. Furthermore, his reforms during this turbulent period of Chinese history did not go unnoticed by his contemporaries, especially westerners. Zhang's Liangjiang military reforms were the most prominent to both westerners at the time and historians in retrospect, resulting in an overemphasis on this period. However, the weight given to Zhang's Liangjiang tenure has often obscured the wider continuities between the Liangguang period prior and the Huguang period to follow.

\section{Nanjing's German-led Army: The Self-Strengthening Army}

As with Liangguang after the Sino-French War, the Sino-Japanese War similarly created the immediate need for a standing western-style army in Liangjiang. Zhang Zhidong detailed his military reforms in Liangjiang in two memorials, one for the army and one for the military academy. Zhang undertook the first and most historically prominent of his Liangjiang military reforms in June of 1895 by creating a new western-style army known as the Nanjing

41 Spence 2013, 214; Wakeman 1975, 192. 
Self-Strengthening Army (Nanjing Ziqiang jun 南京自強軍). ${ }^{42}$ In recruiting intelligent and physically fit soldiers and instructing them in western techniques, Zhang followed the earlier model of the Guangdong Victorious Army. He also used the training distribution methods he first developed in Liangguang. However, the financial prosperity of the Liangjiang region made more resources available for Zhang to use in creating the Self-Strengthening Army.

The Liangjiang area was the economic and agricultural heartland of the Yangzi valley. Adding to the abundance of the region was significant western investment that not only spurred economic growth but also directly added to government revenue through taxes collected by the Imperial Maritime Customs office. ${ }^{43}$ Liangjiang's geography and the western influence made it one of the wealthiest regions in the empire. Zhang Zhidong himself acknowledged that the Self-Strengthening Army was made possible by Liangjiang's prosperity, which allowed him to finance his initiatives with provincial revenues. ${ }^{44}$ Zhang first used this wealth to hire more German military instructors. Compared to the seven foreign officers hired in Liangguang, Zhang increased his foreign staffing fivefold to a total of thirty-five German officers. ${ }^{45}$ The additional instructors allowed him to create a larger army more rapidly. In addition, having more German officers made it possible for Zhang to assign them new and different roles beyond simply training the army.

The German officers quickly went to work training the Nanjing SelfStrengthening Army under Zhang Zhidong's guidelines. Zhang initially drew upon his experiences in Liangguang and organized his new forces along similar lines, modeled after the German army. By the time of his December 1895 memorial, Zhang had already trained over a quarter of the projected ten- thousandman army consisting of eight infantry battalions, two cavalry battalions, two artillery battalions, and one engineer battalion. ${ }^{46}$ As in Liangguang, Zhang planned the forces in accordance with the western organization of combat branches and trained them accordingly. But in Liangjiang, Zhang also formally established a combat engineer battalion to enhance the mobility of

42 Zhang Zhidong, "Xuan mu Xinjun chuang lian yang cao zhe" [Selection and recruitment of the New Army for western training], ZZDQJ, II, $105^{2}$.

43 Spence 2013, 195.

44 Zhang Zhidong, "Sheli hujun ying, gongchengdui lianxi yangcao bing caiying di xiang zhe" [Establishing Protection Battalion, Engineer Squad practicing in western drill by dismissing former battalions for pay], ZZDQJ, II, 1175 .

45 "Chang Chih-tung's Army," North China Herald, January 24, 1896, 139. German officers made 2,772-3,960 taels compared to their Chinese deputies' 288-6oo taels yearly. Zhang 2009, 374 .

46 Zhang, "Xuan mu Xinjun ...," ZZDQJ, II, 1054. 
his army based at Nanjing. While Zhang had touched on engineering tasks in Guangdong, his organization of the Self-Strengthening Army showed an increasingly sophisticated understanding of western warfare and the increased importance of more specialized branches such as combat engineers.

In order to recruit hardy soldiers for the Nanjing Self-Strengthening Army, Zhang enforced the same recruiting requirements as in Guangdong. He required troops to be "between sixteen and twenty years of age with strong bodies.... and able to endure western training." ${ }^{37}$ One of the officials further reported the "first-class" fighting men of the new army were not only physically fit but also literate-an impressive achievement considering China's ten percent literacy rate at the time. ${ }^{48}$ However, these high recruiting standards understandably made it more difficult to attract and retain soldiers without additional incentives. In order to improve the quality of recruits, Zhang settled upon the solution of raising their pay. The basic soldier's pay in the SelfStrengthening Army amounted to about five taels per month, with incentive pay if they performed well. ${ }^{49}$ Zhang also ensured soldiers' uniforms, lodging, and billeting would not be deducted from their pay, as was the practice in traditional Chinese armies.

With more German officers at his disposal, Zhang assigned them to command the Self-Strengthening Army's battalions and companies. The German officers' new roles served a twofold purpose. First, Zhang wanted to "shame" the old Chinese officers in the traditional units and encourage them to conform to western training methods..$^{50}$ Second, putting Germans in command gave his Chinese deputy commanders an apprenticeship to the foreign officers in order to improve their own proficiency. While the governor utilized the German officers to create immediate combat leadership in the Self-Strengthening Army, he ultimately expected the Chinese deputies to assume command after gaining the necessary experience. ${ }^{51}$ The governor selected the deputy commanders not from the ranks of the traditional officers in Liangjiang, but from graduates of his own Guangdong Military Academy and Li Hongzhang's Tianjin Military Academy. ${ }^{52}$ Zhang thereby took advantage of the modest achievements of his

47 Zhang, "Xuan mu Xinjun ...," ZZDQJ, II, 1053.

48 Shen 1903, 4. Because Shen's literacy rate seems low, he is likely referring to classical Chinese literacy and not functional literacy, which has been estimated at about 30 to 45 percent. See Rawski 1979, 23.

49 Zhang 2009, 374; Zhang, "Xuan mu Xinjun ...," ZZDQJ, II, 1054.

$50 \quad$ Zhang, "Xuan mu Xinjun ...," ZZDQJ, II, 1053.

51 Zhang, "Xuan mu Xinjun ...," ZZDQJ, II, 1054.

52 Zhang, "Xuan mu Xinjun ...," ZZDQJ, II, 1054. 
short-lived Guangdong Military Academy to reinforce and bring continuity to his reforms at Nanjing. These officers, already having a base of western military knowledge, would prove the most apt at gaining the experience necessary to eventually shift the army to Chinese leadership.

When the training of the initial force was complete, Zhang again proceeded with a small-nucleus force model to disseminate training to the remainder of the army. Zhang planned to distribute members of the original thirteen battalions trained into thirty battalions to use as the trained nucleus of the larger force. ${ }^{53}$ If the funds allowed, he would continue the process until he reached the projected troop strength of ten thousand soldiers. German officers would slowly be withdrawn from command positions as the Chinese officers finished their apprenticeship phases and moved into the commands. ${ }^{54}$ To Zhang, the Self-Strengthening Army served the security needs of the Qing state and as such would ultimately have to be led by Chinese officers. In training these military officers to serve the Chinese state, Zhang continued to rely upon the western-style military academy.

\section{Regional Prosperity: Nanjing's Military Academy}

The Nanjing Military Academy built upon the model of the Guangdong Military Academy. At the new school, the governor continued recruiting cadets who were physically fit enough to endure hardship but also possessed the literary talents of classical education. Zhang also retained a western curriculum to be taught by the five German officers assigned to the Nanjing Military Academy. With the experience Zhang had gained in Guangdong, his ability to detail his training intentions improved and now included the establishment of combat engineers omitted from the Guangdong Military Academy. Zhang's recruitment criteria continued to emphasize his synthesis of Chinese foundation and western practical use, ultimately serving to defend the Qing state.

The admissions criteria and curriculum of the Nanjing Military Academy showed Zhang's desire to integrate Chinese foundation and western techniques remained intact in Liangjiang. First, Zhang's military academy again attempted to cast a wide net of recruitment by welcoming applicants from outside the academy's home province. ${ }^{55}$ Zhang also continued to emphasize

53 Zhang, "Xuan mu Xinjun ...," ZZDQJ, II, 1053.

54 Zhang Zhidong, "Yu qing xiu bei chu cai zhe" [Suggestions to cultivate, prepare, and store human talent], ZZDQJ, II, 991.

55 While this is not made explicit in Zhang's memorial, Lord Charles Beresford later commented that many of the Nanjing cadets were not local, but from Hunan. Beresford 1899, 112 . 
physical fitness, literary education, and understanding of the cardinal principles of the Chinese classics. ${ }^{56}$ As in Guangdong, the governor recognized the need for skills in basic mathematical calculations and fluency in the German language as the foundation of military education. Zhang argued the technical nature of western warfare warranted study of mathematics, especially in the artillery branch. Furthermore, facility in the German language would allow Chinese officers to remain current with the latest military developments in Europe. ${ }^{57}$ Zhang's focus on elementary education gave his graduates not only the specific technical skills needed in the army of their day but also equipped them to grow with the future evolutions of military science.

One of the key aspects of Zhang's Nanjing Military Academy reform was its national purview. Zhang's memorial to the throne went beyond justification of his own military academy to recommend the "wide establishment of military academies" across China. ${ }^{58}$ In pushing for the establishment of multiple military academies to train talent, the governor looked at the problem of defense not from a provincial perspective, but from a national one. Even when serving as a regional official in Nanjing, Zhang perceived military problems in national terms - and would continue to do so for the rest of his career.

Zhang Zhidong's reforms at Nanjing continued upon the path he had set in Guangdong, but with increased funding for both the western-style army and the military academy. The Nanjing Military Academy's higher budget allowed it to maintain a student-teacher ratio half that of Zhang's later Hubei Military Academy. These funds were predicated on the commercial and economic prosperity of the Liangiiang region. Zhang specifically noted the ability of the Imperial Maritime Customs to supply the academy's budget and also directly requisitioned donations from the local stores and businesses..$^{59}$ The large customs budget and exploitation of the local businesses in the Liangjiang region gave Zhang a unique ability to fund his military reforms during this period.

${ }_{5} 6$ Zhang Zhidong, "Chuangshe lujun xuetang ji tielu xuetang zhe" [Creating the Military Academy and Railroad Academy], ZZDQJ, II, 1089.

57 Zhang, "Chuangshe lujun xuetang ji tielu xuetang zhe," ZZDQJ, II, 1089.

$5^{8}$ Zhang, "Chuangshe lujun xuetang ji tielu xuetang zhe," ZZDQJ, II, 1089.

59 Zhang specifically stated that he would "jiang haiguan ren jiajie mei nian si wan liang" (lit. "Jiangnan customs office every year provides forty thousand taels"), thus directly utilizing customs funds to fund his efforts in Liangjiang. See Zhang, "Chuangshe lujun xuetang ji tielu xuetang zhe," ZZDQJ, II, 1090. 
However, the lack of similar financial capacity when the governor was transferred back to Hubei would necessitate some changes to his reforms there.

\section{Liangjiang Assessment}

The increased size and prominence of the military westernization undertaken at Nanjing created a wider knowledge of these reforms, despite Zhang's short tenure there. In fact, for the Liangjiang period of his career, there are both Chinese and Western assessments of his programs, both of which give them a generally satisfactory evaluation. Chinese sources provided generally positive assessments of Zhang Zhidong's Liangjiang military institutions, while Lord Charles Beresford, a representative of the British Board of Commerce, offered a favorable assessment of the Self-Strengthening Army and Nanjing Military Academy in 1898.

Shen Dunhe, the Chinese official Zhang put in charge of the SelfStrengthening Army, emphasized its elite nature. Shen wrote that the Nanjing Self-Strengthening Army not only trained under the western drill and organization but also used "first-class fighting material as basis" due to the stringent recruiting criteria. ${ }^{60}$ However, Shen's account also revealed the unintended hostility Zhang's policies created between the new forces and legacy Chinese armies in Liangjiang. In June of 1896, shortly after Zhang's departure from Nanjing, Chinese troops armed with traditional swords and spears attacked a company of the Self-Strengthening Army during training. ${ }^{61}$ This event exposed the unintended consequences of Zhang's policy. Instead of causing shame for the older forces and changing their mindset, Zhang inadvertently provoked anger and jealousy. Unfortunately, the altercation resulted in the returned governor, Liu Kunyi, detaching the Self-Strengthening Army to Wusong and halted any new recruitment. ${ }^{62}$ However, the foundations Zhang set were strong. When Beresford visited a year later, the Self-Strengthening Army was still recognized as a model fighting force in China.

Lord Beresford's positive evaluation of the Self-Strengthening Army in 1898, when Governor Liu Kunyi had already curbed the further progress of Zhang's reforms, showed the depth and lasting impact of those reforms. After observing both the drill and battlefield maneuver of the Self-Strengthening Army at Wusong, Beresford commented that the three thousand soldiers "were a fine lot of men, well turned out and well drilled. They had been drilled by German

\footnotetext{
6o Shen 1903, 4 .

61 Shen 1903, 4. The North China Herald also reported this incident in "Nanking"; North China Herald, June 5, 1896, 883 .

62 Gadoffre 1904a, 112-13.
} 
Officers, who had left."63 Beresford's visit also allowed him to also observe the Nanjing Military Academy, which he identified as an "instance of what may be done by the Chinese if properly organized." ${ }^{4}$ While Beresford did not understand that these institutions were the handiwork of Zhang Zhidong, his assessments of the Self-Strengthening Army and Nanjing Military Academy characterized the progress Zhang brought to China's military forces.

During his service as the Liangjiang governor, Zhang Zhidong continued the military reforms he had started in Liangguang and during his initial tenure in Huguang. Zhang persisted in the selective recruitment and training of western-style armies and the establishment of western military academies. Financial prosperity in the Liangjiang region also opened new options for Zhang in reforming the army, such as the creation of significantly larger units, utilization of German officers in command roles, and an increase of soldiers' pay to draw better recruits. As the wartime emergency receded, Liu Kunyi received his transfer orders back to Liangjiang and Zhang Zhidong to Huguang. However, even before Liu Kunyi returned, Zhang was already planning new military reforms for his own governorship in Huguang.

\section{Late Huguang, and Zhang at His Zenith}

Expecting an imminent transfer in late 1895, Zhang issued instructions to the Hubei authorities for his new military projects. ${ }^{65}$ As Zhang arrived back at his Huguang governorship seat of Wuchang in March of 1896, work had already begun. The governor's military focus was clear to even the foreign inhabitants of the city, with a North China Herald correspondent reporting that foreign-drilled soldiers from the Nanjing Self-Strengthening Army had accompanied Zhang Zhidong back to Hubei. ${ }^{66}$ By using this small part of the Self-Strengthening Army as a core of trained soldiers, Zhang broadened his small-nucleus training dissemination to include a cross-provincial character.

63 Beresford 1899, 277. Note that Lord Beresford did not report on the Self-Strengthening Army by name, but as part of his tour of the "Kiangzin" area in the vicinity of Wusong. An inference can be made that the three thousand German-trained troops were the Self-Strengthening Army, as there were no other reports of German-drilled soldiers near Wusong.

64 Beresford 1899, 112.

65 Zhang Zhidong, "Hujun qianying diao E jiaolian pian” [Protection Army Lead Battalion transferred to Hubei for training], ZZDQJ, II, 1103 .

66 "Wuchang," North China Herald, March 20, 1896, 448. 
The group of Nanjing soldiers formed the center of the new army Zhang envisioned for Huguang. Furthermore, the governor's earlier work in establishing the Hubei arsenal had borne fruit by his return, with the Hanyang arsenal producing as many as " 30 Mauser rifles and five quick-firing guns" per day, utilizing the metals from his nearby iron works. ${ }^{67}$ With these armaments and a core of trained soldiers to start his western-style army in Huguang, Zhang was ready to establish the new Hubei Protection Army (E hujun 鄂護軍). ${ }^{68}$

As he had done previously, Zhang quickly followed the new westernstyle army with the establishment of a military academy. The Hubei Military Academy not only continued to use German instructors and a western military curriculum but also explicitly integrated Chinese classical learning, embodying Zhang's ti-yong formula. Yet as western observers such as Lord Beresford and Captain Gadoffre, a French officer, assessed Zhang's military reforms, they were unable to escape the Eurocentric perspective in their evaluations. As westerners did not see the value in Chinese education, Zhang's policy of educational integration and its effects often remained unreported. The observers' western biases tended to obscure the governor's goal of building an officer corps with a background in both Chinese and western education to lead the new army. Unfortunately, many of these biases also seeped into historians' analyses of these same events years later.

Ultimately, Zhang Zhidong's second tour in Huguang was the zenith of his military programs. This tour also provides the widest breadth and depth of primary source materials while remaining understudied in English-language histories. At the core, the governor's methods and institutions continued on the same trajectory until the Qing court mandated empire-wide reforms after the Boxer Rebellion. However, Zhang's reliance upon the Nanjing SelfStrengthening Army as a foundation did not mean his decisions in Huguang were identical to those in Liangjiang. Because the Huguang region was not as financially prosperous as the provinces of Liangjiang, Zhang settled for

67 Imperial Maritime Customs, Decennial Reports 1892-1901, 306; Beresford 1899, 299; Captain Gadoffre also specified the Hanyang arsenal produced the modern 1888 model Mauser rifle as well as rapid-fire guns in German fashion in Gadoffre 1904a, 125 .

There are only a few mentions of this military organization in the English bibliography. Historians either leave it unnamed (Powell) or translate its name as the Hubei Defense Force (Ayers). Instead, I prefer to render the Chinese $E$ hu jun 鄂護軍 as the Hubei Protection Army. This provides more accuracy and continuity with previous translations of the Guang sheng jun 廣勝軍 (Guangdong Victorious Army) and Zi qiang jun 自強軍 (Self-Strengthening Army) where jun was "army" and not "force." Furthermore, "defense" translates more directly to fang 防 while protection translates better to $h u$ 護. Thus my use of Hubei Protection Army for E hujun. 
transformations on a much smaller scale and with a longer timeline that only gradually progressed toward effective Chinese military capability.

\section{Deliberate Progression: The Hubei Protection Army}

Funding issues for Zhang's reforms back in Hubei were evident from the outset. In fact, Zhang directly compared the "insufficiency of the Hubei province treasury, without ability to hire western junior officers" to Liangjiang's "twelve new army battalions, all utilizing western junior officers ... with ease" and no financial issues. ${ }^{69}$ Sent from Nanjing prior to his departure for Hubei, Zhang's memorial of February 5, 1896, already showed both his concerns about funding and his proposed solutions. Zhang instructed the Hubei governor to dismiss two battalions of the original Hubei forces to pay for the one incoming Nanjing battalion..$^{70}$ That Zhang had to dismiss two older battalions in order to fund a single western-style battalion moving into Hubei is indicative of both the financial state of the Huguang region and the increased economic burden of western-style armies. Later that year, when Zhang expanded the core Hubei Protection Army from one to two battalions, he had to dismiss three additional battalions - the Wufang, Wugang, and Zhengnan-to fund it. ${ }^{71}$ As Zhang dismissed these forces, he also critiqued the old recruiting and training methods on similar grounds as he did in Guangdong. Not only did the "Green Standard and brave battalions have many bad habits that make them difficult to train," but the practice of "last-minute recruiting of tens or hundreds of battalions" previously used was no longer effective in modern warfare. ${ }^{72}$ Thus, the repeated discharging of older forces not only reduced expenses but also strengthened the military efficacy of his jurisdiction.

Zhang also operated within the limited finances of Huguang by altering the use of his small-nucleus training in two ways that were distinct from the earlier forms. First, Zhang recognized the Huguang finances "made it impossible to train all battalions at once, and therefore under the constraints of finance we will first train two battalions and the engineer company, that will slowly increase." 73 The governor directly acknowledged his intention to start with only two battalions as the Hubei Protection Army. Second, Zhang also saw the Huguang reforms as a slower process that would continue to expand as funding

\footnotetext{
69 Zhang, "Hujun qianying diao E...," ZZDQJ, II, 1103.

$70 \quad$ Zhang, "Hujun qianying diao E...," ZZDQJ, II, 1103.

71 Zhang, "Sheli hujun ying ...," ZZDQJ, II, 1175.

72 Zhang Zhidong, "Qian tian lian jingbing zhe” [Increasing training of crack troops], zZDQJ, II, 1272.

73 Zhang, "Qian tian lian jingbing zhe," ZZDQJ, II, 1175.
} 
became available in his jurisdiction. By leveraging both a smaller initial force and a longer timeline, Zhang could continue his small-nucleus mechanism of training even while facing financial constraint.

Zhang combined the use of cross-provincial transfers from Nanjing with local recruiting in order to achieve quicker results in Hubei. To increase the capability and size of the organization, in May of 1896 Zhang split the original Self-Strengthening Army's single battalion into a forward and rear battalion by "recruiting more troops to fill both battalions to further train in western warfare." ${ }^{74}$ As in Liangguang and Liangjiang, Zhang selected soldiers only from men with strong physiques and a willingness to endure the hardships of western training. ${ }^{75}$ But as he had learned in Nanjing, recruiting the best soldiers required better pay. To this end, Zhang continued the monetary incentive in Hubei by increasing the troops' pay along with providing uniforms and billeting. ${ }^{76}$ Because these costs contributed to the higher expenses, Zhang had to accept slower reforms. Simply put, Zhang initially accepted a lower quantity of soldiers in order to nurture a higher quality fighting force.

In training the Hubei Protection Army, Zhang relied not only on German officers but also continued to employ Chinese academy graduates. Zhang's transfer of the Nanjing Self-Strengthening Army battalion included five of the thirty-five German officers who had served in Liangjiang. ${ }^{77}$ These officers could immediately start training his army while Zhang negotiated new contracts with Germans to serve in Huguang. Along with German officers, Zhang did not overlook the continued use of Chinese academy officers. Just as in Nanjing, Zhang recruited Tianjin and Guangdong Military Academy graduates to enhance Chinese leadership experience by using them as assistants in Hubei. ${ }^{78}$ Thus, academy-educated Chinese officers took their place beside the Germans to train the Hubei Protection Army.

The curriculum of Zhang's new western-style army in Hubei changed little from his previous armies. The Hubei Protection Army continued to systematize along western tables of organization and train in "western cavalry, infantry, artillery methods, and how to utilize weaponry and ammunition, weapons management maintenance, and engineer, bridging, mapping."79 These tasks

\footnotetext{
74 Zhang, "Sheli hujun ying ...," ZZDQJ, II, 1175 .

75 Zhang, "Qian tian lian jingbing zhe," ZZDQJ, II, 1272.

76 Zhang, "Sheli hujun ying ...," ZZDQJ, II, 1175; Captain Gadoffre's report identified pay ranging from four taels a month to fifteen taels a month. See Gadoffre 1904a, 118.

77 Gadoffre 1904a, 114.

78 Zhang, "Sheli hujun ying ...," ZZDQJ, II, 1175 .

79 Zhang, "Sheli hujun ying ...," ZZDQJ, II, 1175.
} 
aligned with the original three combat branches Zhang had established for the Guangdong Victorious Army and the combat engineers he added in Nanjing. In Hubei, Zhang further detailed the combat engineers not only to build "bridges, repair roads, and conduct construction ... but they also needed to understand the weaponry and military matters." ${ }^{\prime 80}$ In this way, Zhang continued to promote combat engineering as practiced by European armies as a central tenet to his reforms.

Zhang's development of the Hubei Protection Army did not break any new ground from his previous reforms. He continued to emphasize western organization of combat forces focusing on maneuverability and concentration of firepower. However, the financial situation in Huguang pushed the governor to develop more creative solutions. Zhang not only extended the timeframe to spread costs, but also more directly leveraged Liangjiang's resources through inter-provincial transfers. In order to pay for the higher operational costs of western-style armies, the governor forcibly dismissed traditional Chinese forces, which he deemed largely ineffective in modern warfare. Zhang's 1896 methods of disbanding traditional Chinese soldiers to free up finances set a model for later and more prominent reformers such as Yuan Shikai. When Yuan sought funds for his own western-style army after 19oo, he eventually adopted Zhang Zhidong's methods of dismissing legacy formations. ${ }^{81}$ Of course, the funding and establishment of new armies would be ineffective without the proper leadership. Therefore, in his 1896 instructions to academy superintendent Wang Bing'en, the governor again stated his belief that "in training troops, you must also train officers, and with the training of officers, one must rely solely upon the military academies." ${ }^{82}$

\section{Embodying Ti-Yong: The Hubei Military Academy}

In establishing the Hubei Military Academy, Zhang could now draw upon the historical precedents of not only the Tianjin and Guangdong academies, but also the Nanjing Military Academy. In his instructions to Wang Bing'en, the governor detailed the importance of the Tianjin, Guangdong, and Nanjing military academies to the developing military reforms. ${ }^{83}$ To Zhang, the military academy represented the core of cultivating military talent and creating loyal military officers to lead the new western-style armies for China. The governor

\footnotetext{
$80 \quad$ Zhang, "Sheli hujun ying ...," ZZDQJ, II, 1176.

81 Wou 1983, 347-49.

82 Zhang Zhidong, "Zha wei Wang Bing'en deng chouban wubei xuetang" [Appointment of Wang Bing'en to establish the Military Academy], ZZDQJ, v, 3293.

83 Zhang, "Zha wei Wang Bing'en ...," ZZDQJ, v, 3293.
} 
again sought German officers to instruct the cadets, though in Hubei he also used Guangdong and Tianjin academy graduates. Zhang again emphasized the ti-yong formula in the Hubei Military Academy's recruitment and curriculum. But just as with his Hubei Protection Army, the financial constraints of the jurisdiction shaped the depth of officer education and the methods used.

German officers not only trained the Hubei Protection Army but also continued to educate Zhang's officer corps, though they did so in reduced numbers due to the tighter finances. Before he could contract his own military academy instructors, the governor used the officers transferred from Nanjing to temporarily fill the gap. ${ }^{84}$ In the early summer of 1896 , Zhang negotiated a new German contract for Hubei Military Academy instructors. ${ }^{85}$ Even with only two German officers, Zhang again made a point of establishing Chinese authority over the foreigners, this time by assigning a Chinese official to oversee the Germans. In the Hubei Military Academy, Zhang Zhidong's contract with the German instructors specified their subordination to the Chinese academy superintendent. ${ }^{86}$ Zhang's attempts to subordinate the Germans directly to Chinese authority show that even in his use of the most "trustworthy" Germans, Chinese control always took precedence.

The hiring of only two German officers for the Hubei Military Academy, as opposed to the five in Nanjing, was another result of the financial strain in Huguang. Costs of hiring the two German officers totaled approximately 950 taels a month. On top of room and board, the German commandant received about $55^{\circ}$ taels per month and the German instructor received about 400 taels per month. ${ }^{87}$ Comparing the foreign officer pay with that of the Hubei Protection Army, which ranged from four to fifteen taels a month, ${ }^{88}$ the German officers made as much as thirty-five times the salary of a Chinese soldier. Effects of the costs can also be seen in the student-teacher ratio at the new academy. While the Nanjing Military Academy had five German instructors for 150 cadets, ${ }^{89}$ the Hubei Military Academy had two German instructors to

84 "Wuchang," North China Herald, March 27, 1896, 489.

85 Zhang Zhidong, "Zha wubei xuetang Xu dacheng zi song ding Hubei wubei xuetang jiaoxi De yuan hetong" [Military Academy minister Xu delivers Hubei Military Academy German instructors' contract, enclosed], ZZDQJ, v, 3297.

86 Zhang, "Zha wubei xuetang Xu dacheng ...," ZZDQJ, v, 3298.

87 Zhang, "Zha wubei xuetang Xu dacheng ...," ZZDQJ, v, 3299. For the mark-tael exchange rate, see "Exchange," North China Herald, June 5, 1896, 909.

88 Gadoffre 1904a, 118.

89 Zhang, “Chuangshe lujun xuetang ji tielu xuetang zhe," ZZDQJ, II, 1089. 
instruct 120 cadets. ${ }^{90}$ The class ratio difference between the Nanjing and Hubei academies was twofold ( $30: 1$ vs. $60: 1)$. However, Zhang attempted to offset the decrease in western instructors by creating new roles for the western-trained Chinese military academy graduates at the Hubei Military Academy.

Zhang directed Wang Bing'en to employ former Guangdong and Tianjin Military Academy students in the new academy. These Chinese graduates would pair with the German officers and assist with both translation and military instruction. ${ }^{91}$ The use of Chinese instructors helped address the shortage of German officers in Hubei. Zhang tasked not the Chinese supervisor but the German commandant to be in charge of the academy graduates. ${ }^{92}$ The subordination of Chinese academy graduates to a German officer suggests that the role of the former was critical to instruction and not administration. But using Chinese academy graduates did more than compensate for the shortage of German officers. By allowing them to serve as assistant instructors, Zhang created Chinese officers who could instruct future generations. In other words, by assigning the former Chinese academy graduates to serve as instructors in Hubei, Zhang was slowly decreasing the Chinese reliance on foreign officers.

The Hubei Military Academy's admissions process represented Zhang Zhidong's continued dedication to the ti-yong formulation. Yet western accounts largely ignored the foundational Chinese aspects of Zhang's requirements. For instance, the North China Herald published the standard western requirements of "fifteen to nineteen years of age ... chosen according to their height and physical strength" but did not mention the importance of Chinese education and civil or military degrees. ${ }^{93}$ In contrast, Zhang Zhidong's requirements not only demanded physical strength but also embodied his desire "to train military officer talent" by recruiting "students who have pursued an official career or are from the educated literati to enroll and train; this way they will learn faster and to better effects." ${ }^{4}$ The discrepancy between Zhang's account and the western one hints at foreigners' dismissal of the value of Chinese education. Western omissions are even more apparent when contrasted to Zhang's academy entrance proclamation, requiring applicants to "have Chinese literary foundations ... with unity and coherence in writing and understanding"

\footnotetext{
9o Zhang Zhidong, "Zhaokao wubei xuesheng shi, bing zhangcheng" [Proclamation for admittance examinations of Military Academy students, with regulations], ZZDQJ, VI, 4892.

91 Zhang, "Zha wei Wang Bing'en ...," ZZDQJ, v, 3293.

92 Zhang Zhidong, "Zhafa wubei xuetang jicheng ba tiao, fu dan" [Issuing Military Academy regulations in eight articles, enclosed], ZZDQJ, V, 3347 .

93 "Wuchang," North China Herald, March 27, 1896, 489.

94 Zhang, "Zha wei Wang Bing'en ...," ZZDQJ, v, 3293.
} 
and "good physiques and motivation."95 Zhang's entrance proclamation clearly described requirements for both the physical prowess necessary in western militaries and a Chinese classical education that went unreported in the western accounts.

Zhang's curriculum outline for the Hubei Military Academy further emphasized the importance of integrating Chinese classical education and western warfare. The western curriculum remained consistent with Zhang's prior academies and included "cavalry, infantry, artillery warfare and also weaponry, tactical methods and artillery, engineer calculations, and terrain." ${ }^{\prime 96}$ However, Zhang's curriculum in Hubei returned explicitly to his Guangdong curriculum by promoting classical Chinese studies. Zhang desired not just the western curriculum, but also the "study of the Four Books and Chinese military history, this is to solidify classical Chinese learning as foundation." ${ }^{\prime 97}$ With this wording, Zhang directly referenced the ti-yong formulation in the military education context. The Chinese officer corps needed the principles of Chinese society and state ingrained through classical education. If not, then any western learning would not matter. For even the most competent officers, if not dedicated to serving the state, would not strengthen China's ability to defend itself against foreign incursion.

The Hubei Military Academy represented Zhang's ultimate embodiment of loyal Chinese officers competently practicing western warfare. Zhang saw no contradiction in his support of Chinese classical education while simultaneously westernizing the military apparatus. In fact, he saw both sides of the education as essential for national defense. Even as the governor juggled the various aspects of Chinese and western curricula alongside his industrial reforms in Hubei, he found time to personally conduct cadet quarterly examinations at least once a year. ${ }^{98}$ With the amount of attention Zhang Zhidong dedicated to the military, it is no wonder his forces were ultimately assessed as one of the premier armies in China.

\footnotetext{
95 Zhang, "Zhaokao wubei xuesheng shi ...," ZZDQJ, VI, 4892; "Zha wei Wang Bing'en ...," ZZDQJ, v, 3293.

96 Zhang, "Zha wubei xuetang Xu dacheng ...," ZZDOJ, v, 3298.

97 Zhang stated the education should be yi gu zhongxue zhi gen di 以固中學之根底 (lit. "with classical Chinese learning as the root foundation"). See Zhang, "Sheli wubei xuetang zhe," ZZDQJ, II, 1228.

$98 \quad$ Zhang, "Zhafa wubei xuetang jicheng ...," $Z Z D Q J, \mathrm{v}, 3346$.
} 


\section{Huguang Assessment}

The overall assessments of Zhang Zhidong's new military institutions in Huguang showed Zhang's force as one of the best in China. While western observers still found faults, they nonetheless evaluated Zhang's reformed military institutions positively. Captain Gadoffre of the French Army provided one of the most detailed assessments of Zhang's Huguang military institutions during his visit in 1902. Gadoffre saw Zhang's military system in Huguang as "the most important of all China." ${ }^{\text {99 }}$ The Chinese assessment of the governor's forces was equally encouraging. Ultimately, both the Chinese and western assessments of the Huguang military apparatus showed Zhang's successful establishment of a western-style army uniformly equipped, trained upon the western model, and capable of modern warfare. However, even while western observers saw an impressive military, their Eurocentric dismissal of the value of Chinese education resulted in a biased view of the Chinese officer corps.

Western observers saw the competence of the Hubei Protection Army. Lieutenant Brandon of the British Royal Navy visited Zhang's troops in 1900 and observed three thousand men who were all "armed with modern weapons ... manufactured at the Hanyang arsenal."100 This British assessment noted not only the uniformity of weapons Zhang's arsenal provided, but also the growth of Zhang's force since 1896. Thus, while Zhang's reforms were slower in Hubei, he was still able to match the Nanjing Self-Strengthening Army in four years. The Imperial Maritime Customs reports offered a qualitative evaluation of Zhang's troops at the Yichang training camp in western Hubei. The customs officer reported favorably on the "cleanliness, discipline, instruction, and exercise ... [and the] high state of efficiency" of the new Chinese soldiers while stressing their particularly "hardy-looking, active, muscular" nature. ${ }^{101}$ This report shows Zhang's effectiveness in carrying out his high recruitment standards as well as the new training program's ability to enforce western-style discipline and drill. Captain Gadoffre's report further confirms that Zhang's Hubei troops were not only drilled "according to European methods [and were in] every way remarkable,"102 but also specifies that Zhang's forces all used the 1888 Mauser rifle then being used in the German army. ${ }^{103}$ These western assessments of

99 Gadoffre 1904a, 122.

100 Lieutenant Brandon can be found quoted in Powell 1955, 119-20.

101 Imperial Maritime Customs, Decennial Reports 1892-1901, 206.

102 Gadoffre 1904a, 126-27.

103 Gadoffre 1904a, 120. 
Zhang's military forces testify to the efficacy of Zhang's culminating military institutions in Huguang.

While the western observers commented directly on the efficacy of the Hubei Protection Army, Chinese sources provide only indirect assessments of their value to the Qing throne through imperial decrees and orders issued. For instance, when a revolt broke out in Guangxi province in 1903 the throne transferred Zhang's Hubei forces to quell the disorder. ${ }^{104}$ Another transfer followed in 1904, resulting in 2,500 of Zhang's western-style troops moving to Zhili province to buttress capital defenses. During this relocation, one of Zhili's local magistrates expressed his admiration at the Hubei troops' discipline and literacy, and how they were "perfectly under control."105 These transfers of Zhang's Hubei troops showed both the ineffectiveness of the traditional forces in other provinces-by this time Zhang's successor in Liangguang had completely dismantled the Guangdong Victorious Army — and the unmatched reliability of Zhang's forces in the eyes of the Qing government. While the transfer of soldiers does not provide any direct Chinese assessments as to the effects of Zhang's Hubei reforms, it shows the throne's valuation of Zhang's westernstyle armies and their capability to protect China.

The transfers of Zhang's western-style armies also exemplify his prioritization of national concerns over the regional. Zhang first showed his willingness to sacrifice his regional capabilities for the empire when he obeyed the central directives and dispatched his warships to Fujian during the Sino-French War. ${ }^{106}$ In contrast, Li Hongzhang responded to imperial instructions with excuses and delays in order to preserve his own regional naval forces. ${ }^{107}$ Zhang's dedication to the Qing state at the expense of his own jurisdictions continued in his Huguang tenure where he obeyed many imperial transfer orders for his troops. The Guangxi and Tianjin transfers, discussed above, exemplified the governor's loyalty. Furthermore, in 1904 Zhang was also ordered to send not only his soldiers but also his Hubei Military Academy officers to Tianjin. ${ }^{108}$ Ultimately, these orders stripped a good portion of the military capacity Zhang had built in his Huguang jurisdiction, but he nonetheless obeyed with little resistance. Zhang's actions show a regional official who not only understood the state's

\footnotetext{
104 Powell 1955, 156.

105 "Tungchou, Chili," North China Herald, May 6, 1904, 964.

106 Eastman 1967, 157 .

107 Wakeman 1975, 190.

108 "Tungchou, Chili," North China Herald, May 6, 1904, 964; Zhang Zhidong, "Zhi jing lianbing chu Tianjin Yuan gongbao" [To the Commission for Army Reorganization in Beijing, and Yuan Gongbao (Shikai) in Tianjin], ZZDQJ, XI, 9132.
} 
greater needs, but was also willing to sacrifice provincial strength for the betterment of the whole.

Compared with the Hubei Protection Army, the assessment of the Hubei Military Academy showed mixed results. Chinese assessments, while still mainly indirect, seem largely positive. However, the western evaluation provided by Gadoffre depicted the governor's officers as the key weakness. Yet Gadoffre's views were also heavily tinged with Eurocentric bias. In the French captain's own words, Zhang's army had "quite good soldiers commanded by indifferent officers." ${ }^{109}$ As to the cause of the defect, Gadoffre blamed Chinese education. While not attributing the defect to Zhang, he criticized the entrance examination and its focus on "Chinese literature" as well as the "Chinese professors [who] have the charge of certain courses not exclusively military."110 Gadoffre and other western observers' inability to see value in classical Chinese education resulted in biased assessments of the Chinese officer corps. Furthermore, these assessments not only influenced the contemporary westerners in China but also blinded later scholars to a more comprehensive evaluation of Zhang Zhidong's military reforms.

Gadoffre was not alone in his evaluation of the detrimental influence of Chinese educational conservatism. The North China Herald's western correspondents and contributors generally shared this viewpoint and argued that the "futility of the present system of literary examinations" was the main reason for China's weakness. ${ }^{111}$ Aside from such direct statements, reporters also indirectly devalued Chinese education through their reports on Zhang's military reforms. As discussed above, the western reports of Zhang's entrance requirements to the Hubei military academy omitted his pursuit of Chinese literary and military degree-holders in the application process. ${ }^{112}$ Similarly, when there was a substantial reduction in the number of applicants, the North China Herald attributed this to western training being "too hard," even though in reality Zhang had tightened admissions criteria to include only Chinese degreeholders. ${ }^{113}$ As the western observers saw no value in Chinese education, their reporting overlooked the real reason so many applications were withdrawn.

\footnotetext{
109 Gadoffre 1904b, 121.

110 Gadoffre 1904a, 121-22.

111 "The Stirring of China," North China Herald, July 26, 1895, 133.

112 "Wuchang," North China Herald, March 27, 1896, 489; Zhang, "Zha wei Wang Bing'en ...," ZZDQJ, V, 3293.

113 "Wuchang," North China Herald, December 31, 1896, 1137; Zhang Zhidong, "Xiao yu baokao wubei xuesheng shi" [Proclamation of explicit instructions to entering examinations for Military Academy students]," ZZDQJ, vI, 4894.
} 
In this way, western reporters were effectively blind to the purpose of Zhang's second proclamation and unconsciously dismissive of the role of Chinese classical education. Simply put, instead of arguing outright against perceived Chinese defects, westerners ignored the details of Zhang's reforms that did not follow the known evolutionary path to western modernity.

The Chinese appraisal of the military academy was more positive than the western assessments. In December of 1897, Zhang reported the "students are progressing well.... We are pleased; this [education] can transform them into talented officers for the army."114 This evaluation shows his overall satisfaction with the first year of military academy operations. Just as with the Hubei Protection Army, the imperial decrees and transfers also show the Chinese assessment of Zhang's programs. As seen above, the court ordered Zhang's Hubei officers to Tianjin to serve under Yuan Shikai for capital defense. ${ }^{115}$ This transfer demonstrated the importance of the officers Zhang had trained. Another sign of the prestige of the Hubei Military Academy appeared in 1903, when Yuan requested Zhang's advice in his attempt to build his own military academy. ${ }^{116}$ This was the famous Baoding Military Academy, established in 1904 and credited by historians as the first modern Chinese military academy. In the greater scheme of Qing politics, these transfers emerged from Yuan's consolidation of military power in the early years of the twentieth century. The 1901 transfer of Zhang's former Self-Strengthening Army and the 1904 Hubei officer transfer to Yuan demonstrated the latter's desire to control the best western-style armies in China, among which Zhang's forces stood at the forefront.

\section{Conclusion}

From Liangguang to Huguang, Zhang Zhidong pursued consistent military reform processes to build effective military power in China. At the same time, Zhang's increasing knowledge of military affairs and regional distinctions

114 Zhang Zhidong, "Zha wubei xuetang zhong jiaoxi Fa-le-gen-han hui xuetang jiao xi" [Military academy's commandant Falkenhayn returns to the academy to instruct], ZZDQJ, V, 3545. The commandant was likely Erich von Falkenhayn, later to become the German Chief of the General Staff during World War I. Falkenhayn served in China from 1896 to 1902 in various roles to include "instructor for the Chinese Army," likely a reference to his position as commandant of the Hubei Military Academy. Foley 2005, 88-92.

115 Zhang, "Zhi jing lianbing chu ...," ZZDQJ, XI, 9132.

116 Zhang Zhidong, "Zhi Tianjin Yuan gongbao" [To Yuan Gongbao (Shikai) in Tianjin], ZZDQJ, XI, 9016-18. 
shaped the specific techniques he applied in each jurisdiction. Following the Sino-French War of 1884, Zhang's Liangguang tenure was the first iteration of his comprehensive military reform program. This program integrated the Chinese essence within the institutions of the western-style army and military academy and started to adopt western organizations and institutions in the latter. However, Zhang learned from this early experience that effective military capability also required arsenals to create uniform weaponry and railroads to support mobilization. Thus, after the throne ordered Zhang Zhidong's 1889 transfer to Huguang, he first set the foundations for future military institutions by creating the Hubei Arsenal and laying the groundwork for the BeijingHankou railway. Even though Zhang did not initially establish western-style armies or academies in Hubei, his chance to create new military institutions emerged with the onset of the Sino-Japanese War in 1894.

After Zhang's 1894 transfer to Liangjiang, he exploited this more prosperous region to create the Nanjing Self-Strengthening Army and the Nanjing Military Academy. Increased funds in Nanjing allowed Zhang to hire more German officers while also increasing pay for the army. Zhang carried the new tools he acquired from his Nanjing experience with him when he returned to Huguang in 1896. This second Huguang tour marked the culmination of his ideas on military reform, knowledge, and experience. In Hubei, he continued the higher pay to attract better soldiers but had to extend the training timeline, disband traditional soldiers, and reduce the number of German officers in order to reduce costs. However, Zhang mitigated the effects of the reduction by employing former Chinese academy graduates to both train his Hubei Protection Army and teach at the Hubei Military Academy. In the Hubei reforms, Zhang adopted from Nanjing what he believed was financially feasible in this less affluent region. The new military academy and western-style army ultimately matched and surpassed his earlier reforms. In fact, at the turn of the century, before Yuan Shikai's Zhili governor-generalship and military reforms began, Zhang's military institutions were quite possibly the best in all China.

The historical impact of Zhang Zhidong's military reforms extended beyond the armies and military academies he established. His influence even stretched beyond Yuan Shikai's own military power, which owed much to Zhang's western-style forces and officers. More difficult to discern is whether Zhang met his objective of creating an effective combat force for China. Part of this is due to the difficulty of transcending the Eurocentric perspectives that were prevalent in western evaluations. While westerners were in the best position to judge how close Zhang's western-style armies came to their own standards, their biases also limited their sensitivity to broader Chinese aims. Both later historians and observers at the time failed to discern Zhang's intent to 
create not just a western-style army, but one that was enhanced with the values of classical Chinese education.

This study of Zhang Zhidong's military reforms adds to the emerging narratives of successful late-Qing state building. Zhang's creation of western-style armies and military academies in his jurisdictions is evidence of successful military state building. These reforms did not just occur at the provincial level, but also often indirectly expanded into wider Chinese institutions via troop transfers, especially in the later part of Zhang's career. The later Qing military reforms undertaken by the Commission for Army Reorganization and the establishment of the national army organization improved Chinese military capability directly from a national level, but it built upon the foundations previously set by Zhang Zhidong. ${ }^{117}$ While all of these new institutions undoubtedly had their limitations and shortcomings, they nonetheless demonstrated a rapid development of the Chinese military. Direct historical assessment of their combat efficacy must remain an unanswered question, since neither Zhang's forces nor the new Qing armies that followed ever had an opportunity to demonstrate their progress in armed conflicts against their contemporary western counterparts.

\section{References}

\section{Primary Sources}

ZZDQJ Zhang Zhidong. Zhang Zhidong quanji [Complete Works of Zhang Zhidong]. Edited by Yuan Shuyi, Sun Huafeng, and Li Bingxin. 12 vols. Shijiazhuang: Hebei renmin chubanshe, 1998.

Beresford, Charles. 1899. The Break-up of China. New York: Harper.

Chinese Times. Tianjin.

Gadoffre, Captain 1904a. "Chinese Troops and Their Instructors." Translated by Major James Rockwell. Journal of the United States Infantry Association (July 1904), 111-27.

Gadoffre, Captain. 1904b. "Chinese Troops and Their Instructors, Concluded." Translated by Major James Rockwell. Journal of the United States Infantry Association (October 1904), 117-28.

Imperial Maritime Customs. Decennial Reports 1882-1891. Shanghai, 1893.

Imperial Maritime Customs. Decennial Reports 1892-1901. Shanghai, 1904. North China Herald. Shanghai.

117 Powell 1955, 242. 
Shen, Tun-Ho [Dunhe]. 1903. Recollections of a Chinese Official. Edited and arranged by L.D. Shanghai: Reprinted from North China Herald.

\section{Secondary Sources}

Ayers, William. 1971. Chang Chih-tung and Educational Reform in China. Cambridge, MA: Harvard University Press.

Bays, Daniel H. 1978. China Enters the Twentieth Century: Chang Chih-tung and the Issues of a New Age. Ann Arbor: University of Michigan Press.

Biggerstaff, Knight. 1961. The Earliest Modern Government Schools in China. Port Washington, NY: Kennikat Press.

Cameron, Meribeth E. 1938. "The Public Career of Chang Chih-tung." Pacific Historical Review $7 \cdot 3$ (September 1938), 187-210.

Chang, Chung-li. 1962. The Income of the Chinese Gentry. Seattle: University of Washington Press.

Eastman, Lloyd E. 1967. Throne and Mandarins: China's Search for a Policy during the Sino-French Controversy. Cambridge: Harvard University Press.

Fairbank, John K. 1992. China: A New History. Cambridge, MA: Belknap Press of Harvard University Press.

Foley, Robert T. 2005. German Strategy and the Path to Verdun: Erich von Falkenhayn and the Development of Attrition, 1870-1916. New York: Cambridge University Press.

Fung, Allen. 1996. "Testing the Self-Strengthening: The Chinese Army in the SinoJapanese War of 1894-1895." Modern Asian Studies 30.4 (October 1996), 1007-31.

Guy, R. Kent. 2010. Qing Governors and their Provinces: The Evolution of Territorial Administration in China. Seattle: University of Washington Press.

Halsey, Stephen R. 2015. Quest for Power: European Imperialism in the Making of Chinese Statecraft. Cambridge, MA: Harvard University Press.

Hummel, Arthur W. ed. 1943. Eminent Chinese of the Ch'ing Period. 2 vols. Washington, D.C.: U.s. Government Printing Office.

Kennedy, Thomas L. 1978. The Arms of Kiangnan: Modernization in the Chinese Ordnance Industry, 1860-1895. Boulder, co: Westview Press.

Li Xizhu. 2009. Zhang Zhidong yu xinzheng yanjiu [A Study of Zhang Zhidong and the Late Qing New Policies]. Shanghai: Shanghai shudian.

McCord, Edward A. 1993. The Power of the Gun: The Emergence of Modern Chinese Warlordism. Berkeley: University of California Press.

Morse, Hosea B. 1921. The Trade and Administration of China. Reprint, New York: Russell and Russell, 1967.

Peake, Cyrus H. 1970. Nationalism and Education in Modern China. New York: Howard Fertig.

Powell, Ralph L. 1955. The Rise of Chinese Military Power. Princeton, NJ: Princeton University Press. 
Rawski, Evelyn Sakakida. 1979. Education and Popular Literacy in Ch'ing China. Ann Arbor: University of Michigan Press.

Rowe, William T. 2009. China's Last Empire: The Great Qing. Cambridge, MA: Belknap Press of Harvard University Press.

Spence, Jonathan D. 2013. The Search for Modern China. 3rd ed. New York: W.W. Norton. Wakeman, Frederic, Jr. 1975. The Fall of Imperial China. New York: The Free Press.

Wang, Jianhua. 1995. "Military Reforms, 1896-1908." In Douglas R. Reynolds, ed. China, 1895-1912: State-Sponsored Reforms and China's Late-Qing Revolution. Armonk, NY: M.E. Sharpe, $67-84$.

Wou, Odoric Y.K. 1983. "Financing the New Army:Yuan Shih-k'ai and the Peiyang Army." Asian Profile 2.4 (August 1983), 339-56.

Zhang Yiwen. 2009. "Zhang Zhidong yu Ziqiang jun" [Zhang Zhidong and the SelfStrengthening Army]. In Yuan Shuyi and Zou Jincai, eds. Zhang Zhidongyu Zhongguo jindaihua [Zhang Zhidong and China's Modernization]. Beijing: Zhonghua shuju, 370-79. 